\title{
How the Concept of "African Solutions for African Problems" Can Be Applied to Resolve the GERD Dispute
}

\author{
Biruk Kedir Mohammed \\ School of International Relations, University of International Business and Economics, Beijing, China \\ Email: bkedir@gmail.com
}

How to cite this paper: Mohammed, B. K. (2021). How the Concept of "African Solutions for African Problems" Can Be Applied to Resolve the GERD Dispute. Open Journal of Political Science, 11, 594-613. https://doi.org/10.4236/ojps.2021.114038

Received: July 4, 2021

Accepted: August 27, 2021

Published: August 30, 2021

Copyright (อ 2021 by author(s) and Scientific Research Publishing Inc. This work is licensed under the Creative Commons Attribution International License (CC BY 4.0).

http://creativecommons.org/licenses/by/4.0/

\begin{abstract}
The concept of "African Solutions for African Problems-ASAP" is promoting as a viable option to address the Grand Ethiopian Renaissance Dam (GERD) dispute. Previous studies focused on the broader Nile River issue. However, the dynamics of African-led mechanisms haven't received proper scholarly attention. Thus using secondary data, this research will figure out how the concept of ASAP can be applied and the enduring challenges. The major findings are the earlier legal frameworks mainly (the contentious 1929 and 1959 treaties) about the utilization of the Nile River, nationalistic interests and alliance formation and extra-regional powers intervention in the GERD dispute. The concept can be applied through enhancing the AU-led negotiations and in long run through strengthening the sub-regional mechanisms such as the NBI and commonly accepted frameworks.
\end{abstract}

\section{Keywords}

African Solutions for African Problems, AU, GERD, Nile River Dispute

\section{Introduction}

In a recent period, transboundary water resources became the major source of tension among states. Also, water became a security issue mainly due to two reasons; overpopulation and climate change (Krampe et al., 2020). In the earlier times, oil was the major source of energy; however, water became important resource in the form of generating hydroelectric power as well as has the potential to protect the growing influence of climate change (Claudious Chikozho, 2012). In a place where there is a shortage of water resources, the people suffer from drought, diseases and they are forced to leave their homes and migrate in search 
of better settlement areas. As a result, transboundary resource management and the water governance issue became an important aspect of global politics. Due to this, there are lots of agreements and bilateral, trilateral and multilateral negotiations either through established institutions or regimes (Any Freitas, 2013).

In the African context, the continent has abundant resources of water and it can be a huge potential for its development. In Africa, the major areas of tension are North-Eastern Africa mainly between Ethiopia, Egypt and Sudan. In the Western African region, the Senegal River and Volta River are also sources of conflict. The region includes Ghana, Burkina Faso, Senegal and Mauritania. The Central African region also includes Mali, Niger and Nigeria. In the Southern African region, Botswana, South African Republic, Lesotho, Namibia and Angola has also disputes over the use of the Okavango River. Generally, River Nile, River Delta, River Volta and River Zambezi are the most widely contentious water rivers. Among all these rivers, the Nile River Basin is becoming the most studied as well increasingly getting international media coverage as well as scholarly attention (Claudious Chikozho, 2012). Therefore, in the continent, water resource management increasingly became the source of disagreement between various states.

In some of the African states, such as the Horn of African region, there are pastoral conflicts, inter-communal clashes as well as intrastate wars. Among the reasons, desertification, searching for better farmlands and settlement areas became a source of contention. These conflicts caused a large number of forced migration and internal displacement (Abadir, 2011).

The Nile river issue is the most contentious issue in international politics (Krampe et al., 2020). It is also considered as the oldest dispute in the continent. In terms of the Nile Water share, the largest contributor of the Nile (86\%) came from the Ethiopian highlands and $14 \%$ of the water came from White Nile (Lidet, 2019). Due to the Nile River, states in this region have mutual suspicion and mistrust. The conflict and cooperation date back to ancient times. Since the times of the ancient pharaohs, various rulers of Egypt used to send gifts to the ancient Ethiopian rulers as part of ensuring the flow of Nile River (Lidet, 2019). Egypt has used its diplomatic potential and the pre-existing agreements (1929 and 1959), successfully can hinder the construction of megaprojects on the Nile River. Due to this Ethiopia couldn't able to construct major projects since the launching of the Grand Ethiopian Renaissance Dam (GERD) in 2011 (John, 2020; Treszkai, 2018).

During the last decades, there were various efforts to bring cooperation among the Nile River basin through continental, regional and sub-regional mechanisms. However, previous attempts didn't achieve cooperation among the states (Any Freitas, 2013). Since the early 1990s, the Nile River Basin Initiative (NBI) is established to achieve mutual cooperation among the states in the basin. In 2015, the three countries agreed on the declaration of principles (Krampe et al., 2020). Despite these efforts, mainly Egypt and Sudan couldn't agree on the Ethiopian GERD issue. Since 2020, the dispute is handled by the AU-led framework. This 
process underlines the concept of African solutions for African problems. However, there is a dispute over the mechanisms of solving the problem (Dereje, 2010; John, 2020; Laurie, 2013).

Though there is an increasing piece of literature in the area of the Nile River dispute, the potential impacts of African-led mechanisms in resolving the ongoing tensions are not properly studied. Therefore, this article will give answers to the following questions; how the concept of African solutions for African problems can be defined? What are the major barriers to applying the concept and how the concept can be applied to resolve the Nile River dispute? The research used secondary data mainly from books, published documents from reliable governmental and non-governmental organizations. This article is organized into four parts: the first section will assess the conceptual development of ASAP; the second section will figure out the problem in context and explain the nature of the GERD dispute on the Nile River Basin; the third section will assess the major problems of applying the concept of ASAP and the fourth section will present how the concept can be applied in resolving the GERD dispute as follows.

\section{African Solutions for African Problems: Conceptual Development}

The concept of "African solutions African problems" is defined as a rallying and emotive idea that is used as an instrument of fostering continental solutions (Faibt, 2019). The concept is mainly used in the area of economic development, social development and gradually in the area of peace and security to show the solidarity of applying continental mechanisms to solve the African problems.

During the times of African decolonization in the 1960s, the African anti-colonial leaders such as Kwame Nkrumah of Ghana emphasized the need for establishing African regional responses for the Africa security problems through regional security arrangements (Laurie, 2013). From this, the concept of African solutions for African problems began to develop. At the outset, the concept of African solutions for African problems (ASAP), indicates a sense of self-reliance, pride, self-responsibility, and offering indigenous solutions at once served as rallying issue to solve continental problems (Laurie, 2013; Remofiloe, 2017).

As a result, the establishment of the Organization of the African Unity (OAU) and lately revitalized itself into the African Union (AU) showed the African states' interest to establish continental ways to solve African problems. Various forms of security arrangements such as the African Union Peace and Security Council, the African Standby Force, the Continental Early Warning System and related initiatives are established from the concept of ASAP (Laurie, 2013; Mehari, 2020).

As Mays (2003) emphasized there are three factors for the adoption of the African solutions for African problems. These factors are the reduction of external powers' influence in continental affairs and the neglect of the global south from the Superpowers mainly in the post-Cold War period; secondly, the west- 
ern powers withdraw from the African conflict areas such as Somalia and failed to give timely response during the Rwandan Genocide. This created vacuum in delivering collective response in the continent and left the mechanisms for continental ways. Thirdly, in some of the regions in the continent, the development of regional hegemonic powers provides continental and regional responses for African problems (Rawia, 2018).

One of the driving factors in the African mechanism is the Charter of the Organization of the African Unity (OAU) which signifies the importance of "Try the African mechanism first" during the conflict resolutions between member states in the continent. The establishment of various regional and sub-regional organizations and supranational institutions signifies the importance of resolving conflicts through African mechanisms. The Pan-African thoughts are mainly focused on enhancing and fostering the solidarity of African states based on the consent of the African mechanisms to solve their own social, economic and political problems. The mediation efforts through the African-led mechanisms would give an opportunity towards the Pan-African approaches (Remofiloe, 2017).

Though there are frameworks to implement the African solutions for the African problems, there are commitment gaps of the African leaders to put the agreements into practice. Mainly, reliance on external funding makes the African mechanisms depend on foreign powers' intervention. The heavy dependence makes the AU adopt donor's interests. Though there are various regional and sub-regional mechanisms there is long-established and deep mistrust among the African states. This division became the major hindrance to standing together for common interests (Public Service Commission, 2020).

The following section gives the major predicaments of applying this concept in the Nile River dispute mainly in the GERD issues and the mechanisms to apply the concept.

\section{The Problem in Context: The Dispute over the GERD on the Nile River Basin}

The Nile River is the longest river in the world that covered one-tenth of the African continent. The two major sources of Nile River are mainly the Ethiopian plateau (Abbay River) and the Great Lakes. The Blue Nile source is from Lake Tana and the White Nile source is from Lake Victoria in Uganda. The two sources (Blue Nile and White Nile) merge in Sudan, Khartoum and finally ended in the Mediterranean Sea. Most of the countries in this river basin live below the poverty line; the region is also a conflict-prone area and threatened by environmental degradation (El-Fadel, El-Sayegh, El-Fadl, \& Khorbotly, 2003).

Among the countries in the Nile Basin, Egypt and Sudan are heavily dependent on the river. $96 \%$ of Egyptians renewable water resources and $85 \%$ of Sudanese are dependent on the flow of the Nile River. They used it mainly for irrigation purposes and hydroelectric power generation. Moreover, the Nile River is a source of agricultural production and $80 \%$ of the downstream countries use it 
for the purpose of large-scale farming production. Due to its vitality, the countries in this region see the river not only as in the context of its economic importance but they portrayed it as their national security agenda (Mehari, 2020).

As a result, the issue of Nile River rivalry is the most contesting agenda in the North Eastern Africa region (Krampe et al., 2020). Also, rivalry is considered as a source of insecurity in the continent. There are divergent interests in the Nile river basin. Mainly there are two areas of disagreements in the Nile River basin. All the Nile river riparian countries have concerns about the utilization of the river and the CFA (Yohannes et al., 2017).

The second and most contesting area of disagreement is mainly between Ethiopia, Egypt and Sudan. For Egyptian, the Nile River is considered as the major source of energy and in most of the literature, the Ancient Greek Historian Herodotus in 460 BC said "Egypt is the gift of the Nile" (Mehari, 2020). For centuries, Egypt continued to claim the historical rights of using Nile River and threatened other riparian states from using the water (John, 2020). Though Ethiopia has an 86 percent share of the Blue Nile River, for a long period of time, Ethiopia didn't use the river properly until the launching of Africa's biggest hydroelectric dam, the Grand Ethiopian Renaissance Dam (GERD) in 2011. The water doesn't give meaningful life to Ethiopia. Back in the 1970s, Ethiopia planned to construct a dam in the Nile River and the US Company conducted an impact assessment study. However, at the time Egypt threatened to attack Ethiopia and launched diplomatic warfare on Ethiopia to dissuading financial access for the construction of the dam (John, 2020).

In 2011, Ethiopia launched the construction of the Grand Ethiopian Renaissance Dam (GERD) by the later Prime Minster Meles Zenawi. The dam is (the African largest and the world $10^{\text {th }}$ largest dam which aimed to increase Ethiopian hydroelectric energy capacity by fivefold (Bearak \& Raghavan, 2020). The dam has a 74 billion cubic meter storage volume, $145 \mathrm{~m}$ high and 1708 meters wide. The total reservoir area is $1874 \mathrm{~km}^{2}$. After the completion, the dam has the potential of generating $6000 \mathrm{MW}$ of electric energy. The GERD is expected to generate electric power in 2023. During the launching of the dam, Egypt and other Arab and Middle Eastern States were in the public uprising and the Arab Spring was a major political movement (John, 2020; Misha, 2019).

Considering the major benefits of the GERD, mainly this project is aimed to generate hydroelectric power of $6000 \mathrm{MW}$, with an annual production of 15,130 GWH per year and it can cover the power supply-demand of Ethiopia as well as the Horn of African region. Though Africa is considered as the "water tower" and has abundant water resources, the continent only generates 4 percent of the global electricity share mainly from South Africa, Egypt and other countries. However, the completion of GERD will increase the African share of hydroelectric energy with a considerable amount. Based on the World Bank study, only $24 \%$ of the Sub-Saharan population has access to electricity. Due to the low coverage of hydroelectric power, the level of industrialization is also low in this re- 
gion. Besides, as a result of the rapid growth of population, the energy consumption need is also increasing (John, 2020).

Above all, the GERD is considered a flagship project for Ethiopia and it is a symbol of national pride. Therefore, it has a rallying effect since the project is Africa's largest dam that is constructing by local financial sources including the public fees. For Ethiopia the construction of GERD has aimed to increase the internal energy production capacity. The GERD is a response to the country's shortage of electricity where 65 percent of the populations couldn't get access to electricity. Besides, expanding the country's domestic electric energy capacity, Ethiopia also could sell electricity to its neighboring states and ultimately strengthen regional connectivity (Anwar, 2017). Unlike some other oil-dependent and mineral-rich countries in the continent, Ethiopia's major resource is its water that can be a potential for hydroelectric power. This eventually will boost the rural electric coverage, speed up industrialization and bring a fundamental shift for tackling poverty in the country. Therefore, the construction of GERD is vital for domestic energy consumption, expanding irrigation farming and industry. Besides, after the completion of the GERD, it has a human-made lake that can be used for establishing the tourism industry (John, 2020).

The benefit of this project is not limited to power supply. The other viable benefit is the mitigation of drought and reduction of flood during the heavy rainy seasons. Various studies indicated that GERD has the advantage for regulated flow of water in the dry seasons. This regulated flow of water will create additional advantages for the increased production of agriculture in downstream countries and minimize the harvest losses caused due to water shortages. Besides, the GERD will offer an advantage for power add energy production of hydroelectric dams in downstream countries through the flow of sediment-free and regular flow of water throughout the year. Therefore, the downstream countries (notably Egypt and Sudan) will be beneficial in the GERD project due to the steady flow of water throughout the year (Misha, 2019).

The other important benefit is sedimentation management in the downstream countries. For example, the Sennar Dam and the Roseires Dam in Sudan which are constructed in the Blue Nile lost $71 \%$ and $36 \%$ of their electric generation capacity since their operation year respectively. Moreover, the Aswan High Dam in Egypt is also affected by the sedimentation problem. The two governments were forced to spend huge costs for maintenance purposes, to close the irrigation channels and other infrastructural costs. However, after the GERD is completed this sedimentation problem will be significantly decreased. In some studies stated that $86 \%$ of the sedimentation will be reduced after the GERD is completed in its full capacity. In addition, the GERD will reduce the evaporation loss from the dams which are operating in the downstream countries. Mainly the Egyptian Aswan High Dam and Sudan's Aulia dam are beneficial in this regard (Yihdego, Rieu-Clarke, \& Cascão, 2016).

Despite the above benefits, the construction of the dam has different res- 
ponses in the river basin. Egypt sees the dam as a security threat. The concerns of Egyptians about the dam are, it can reduce the flow of freshwater to Egypt and during the filling process, and $25 \%$ of the water share could be minimized. Besides, the Egyptian scholars argued that the GERD will reduce the volume of electricity which is generated by the Aswan High Dam. Therefore, considering these threats, Egypt asks guarantee on the filling and the overall operation process. Since the unilateral decision of Ethiopia to build the largest dam in the Nile River, Egypt repeatedly raised concerns about the safety, operation and security of the project. Mainly, about the filling process of the dam, Egypt argued that if the filling of the dam is conducted within short period of time it will affect the water security of the downstream countries. On Sudan's side, initially, the Sudanese officials repeatedly described that the dam has positive benefits for Sudan in terms of preventing floods and it can also be a source of electric energy. They expressed their support for the construction process considering its opportunity to prevent the devastating floods which have negative consequences for more than 700,000 Sudanese in the border areas in the Southeastern border with Ethiopia. Also, they aimed to get cheap electricity from GERD after its completion. However, lately, various officials changed their narratives and begun to describe the negative impacts of the dam and shifted their stands towards Egypt. Thus, Egypt and Sudan raised concerns about the filling and operations of the project (Public Service Commission, 2020).

In 2014, the three countries (Ethiopia, Egypt and Sudan) agreed to deploy the Independent Panel of Experts (IPE) to scrutinize the potential impacts of the GERD on the Nile River Basin. The experts studied the impact of the dam on the three riparian states and mainly the ministerial committee made a discussion based on the recommendation of the IPE. Though the Independent Panel of Experts studied that the dam has benefits for both the upstream and downstream countries, Egypt has no willingness to accept the recommendations of the experts. In 2015, the three states agreed to study the further environmental impact of GERD. As it is observed in various negotiation processes, Egypt is reluctant to accept the potential benefits of the dam and openly arguing for its historic rights on the water resources. In some researches, the dam has positive contributions mainly by providing proper flow of water and it has also positive impact on reducing evaporation losses. However, these scientific suggestions are not supported by the Egyptian side, due to the long-established political interests (John, 2020).

Thus, Ethiopia rejected all these claims and stress that the construction and filling of the dam are mainly conducted by Ethiopia based on the Declaration of Principles (DOP) which was signed in 2015. Moreover, Ethiopia persistently argued that the dam will have no significant impact on the natural water flow of the Nile River. Thus, Ethiopia is arguing that the GERD is a major hydroelectric power that aimed to afford electric power and is part of the development plan of the country. The Ethiopian officials and technical expertise repeatedly stated that 
the GERD has positive impacts on all the riparian states. Moreover, Ethiopia argued that the filling process has no significant harm for other countries in the basin and the GERD is constructing for the purpose of generating hydroelectric power. Thus its effect will be minimal. On the contrary, GERD has a positive impact in terms of reducing flood and silting and boost water conservation as well as generate energy for the region. Mainly, for the downstream countries, the provision of cheap energy, the ability to flood control and reduction of excessive water loss are the major positive impacts (Tesfa, 2013).

Therefore, based on the long-established dispute, it is vital to scrutinize why the Nile Basin countries mainly the three contending states can't agree on the issue? What are the major predicaments of the African-led process? How the concept of African solutions for problems can be applied to resolve the GERD dispute? To what extent extra-regional actors are intervened in this process and how it affects the continental-led mechanisms? These questions will be addressed in the following section.

\section{What are the Major Challenges of Applying the Concept of African Solutions for African Problems in Resolving the GERD Dispute?}

The above section covered the problem statement of the GERD dispute in general and the following part will mainly be focused on the major barriers of applying the concept of the African Solutions for the African Problems (ASAP) particularly in the GERD dispute. These barriers are the earlier legal frameworks about the utilization of the Nile River, Nationalistic Interest among the states in the basin and extra-regional actors' intervention will be discussed in detail as follows.

\subsection{Earlier Legal Frameworks about the Utilization of Nile River}

There are various International laws and codes about the utilization of transboundary water resources. The major attempt was made by the Helsinki Rules of the Uses of the Waters of International Rivers (Claudious Chikozho, 2012). Though the UN-led facilitated the process, the UN General Assembly was not adopted it due to the objection of some member states. About the utilization of Nile River and the Nile Basin Cooperation, all the treaties and agreements are not fully or partly accepted by the states in the region. In between 1891-1959, there were eleven bilateral agreements and they were mainly signed by the former Colonial power Great Britain and Egypt, Great Britain and Italy, Great Britain and Ethiopia, Great Britain and the Congo, Great Britain and Belgium and Egypt and Sudan (Any Freitas, 2013). This indicated that most of the treaties and agreements were signed between the former colonial powers mainly Great Britain and states in the region and the treaties have bilateral bases. The 1959 agreement was made between Egypt and Sudan (Krampe et al., 2020). In this agreement, Ethiopia, the major contributor of the Blue Nile, was not represented 
and the agreement was mainly dictated by the British colonial aspirations. Due to this Ethiopia rejected the 1959 agreement in any Nile river agreements since the country was represented at the time and excluded all the other riparian states (Lidet, 2019).

The 1959 agreement is considered valid mainly by Egypt and Sudan; however, the upstream countries mainly represented by Ethiopia rejected this claim (Dahilon, 2003). As a result of this, the relations of the downstream and upstream countries in the Nile River are characterized by mistrust, disagreements and the water issue developed into regional security agenda for a long period of time. Based on this treaty, Egypt has the right of using 55.5 billion cubic meters of water and Sudan has 18.5 billion cubic meters of water tough Sudan didn't use this share properly (El-Fadel, El-Sayegh, El-Fadl, \& Khorbotly, 2003).

Although the downstream countries (Egypt and Sudan) continuously argued that the 1959 negotiation could be served as a legal tool for the management and allocation of the river, the upstream countries (mainly Ethiopia) rejected this framework (Krampe et al., 2020). The agreement allocated solely the water to the two countries and denied the rights of the upstream countries to use it for their development. Due to the heavy dependence of Egypt on the Nile River, there is a long-established reluctance to change the enduring agreements and change the statuesque (Mehari, 2020). This reluctance to include the changing interests and accommodate the interest of all the other concerned states makes cooperation difficult to achieve.

Though there are various treaties between the riparian states, there is no inclusive agreement between all the riparian states that can represent the interests of all the downstream and upstream states in the Nile River Basin. Therefore, these previous treaties became the major source of contention between the riparian states and make the concept of African solutions for African problems difficult to apply.

\subsection{Nationalistic Interests and Alliance Formation}

In line with the African-led mechanisms, the major problem is narrow national interests in the cooperation process (Rawia, 2018). The ongoing dispute over the issue of GERD and the CFA is manipulated by nationalistic politics to shift the domestic political goals (Any Freitas, 2013). There are continuous nationalistic interests in the negotiation process. So far the biggest hydroelectric project in the Nile River is the Egyptian Aswan High Dam which has 60 years of age and is taken as a symbol of the Egyptian dominance and hegemonic power on the river (Dereje, 2010). Besides, the Aswan Dam provided electric power and also gives a strategic geopolitical advantage for Egypt. After the completion of the GERD, the status quo set by the Egyptian Aswan Dam will be shifted to Ethiopia (John, 2020). Moreover, it can be a source of regional hegemonic shift in the Northeastern and Horn of African region (Mulat \& Moges, 2014). Egyptian leaders used the narratives of Herodotus as a moral statement to endure the hegemonic pow- 
er over the use of the Nile River for a long period of time (Mulat \& Moges, 2014). However, the upstream countries mainly Ethiopia and other states have increasingly challenged the hegemony of Egypt.

Egypt used three major strategies to impede Ethiopia's plan to construct any project in the Nile River (Yihdego, Rieu-Clarke, \& Cascão, 2016). These strategies are first, threatening with military capacity. Alongside the negotiations, Egypt and Sudan launched joint military exercises and the President of Egypt warned Ethiopia that all options are open to keep the national interest of Egypt. Thus, Egypt and Sudan made a joint military alliance in the name of "Guardians of the Nile" which consists of the air force, land and naval forces of the two countries. Secondly, using its diplomatic channels Egypt persuaded international funding agents to refrain from giving financial aid to Ethiopia's projects on the Nile River. However, understanding this challenge, Ethiopia announced that the dam is fully funded with internal sources including public contributions. Thirdly, due to the Nile River Rivalry, Egypt has been continuously supporting various domestic rebel groups (including the secessionist groups) in Ethiopia (Anwar, 2017; John, 2020; Yihdego, Rieu-Clarke, \& Cascão, 2016).

All the upper riparian countries (notably Ethiopia) rejected the claims of Egypt mainly due to three reasons. 1) The interest of continuing the colonial era agreements couldn't be applicable to the upstream countries and at the time Ethiopia was not represented and most of the others were under colonial rule. Therefore, the colonial time treaties couldn't be binding for all the NBI member states; 2) An exclusive approach in the Nile Basin is not fair and equitable and unacceptable in the international law; 3) The Nile Basin states, most of them are underdeveloped and has the poverty alleviation programs that demand extensive use of water. Therefore, all the NBI states need to use the Nile and its tributaries and don't allow exclusive use of the water resource by single states. The shared resource should be used in a shared manner through a well-established legal mechanism (Abadir, 2011; Anwar, 2017).

After the dam construction is continued, Egypt mainly focused on the management of the filling of the dam after legally binding principles. In every step, the efforts of Egypt became showing the filling of the dam as an existential security threat for the country. Egypt wants the filling of the dam in a longer period of time.

\subsection{Extra Regional Powers Intervention in the GERD Dispute}

One of the barriers in the GERD dispute is the intervention of extra-regional powers mainly the US. In 2019, after the President of Egypt, Abdulfetah Alsisi requested to the President of the US, Donald Trump to mediate the GERD talks, the US government facilitated the meeting that incorporates the three countries Ministry of Foreign Affairs and Ministry of Irrigation, Energy and Water (US Congress, 2020). President Trump represented Treasury Secretary Steven Mnuchin to ratify the agreement paper for the three countries. As a result of the wa- 
ter security agenda, various international actors' mainly superpowers are concerned about the issue of managing disputes between various disputant states. They seek to exert their influence in Africa (European Union, 2021). However, the superpowers' engagement not always emanates from solving the dispute in an amicable way. For example, in October 2020, US President Donald Trump, in a broadcasted phone call with the Sudanese Prime Minster, said "Blow UP the Dam" supporting the Egyptian side in the dispute of Ethiopia, Sudan and Egypt (John, 2020).

Thus the involvement of the US in the GERD dispute has the following flaws: The three countries didn't agree on the role of the US in the negotiation process. The decisions of the Trump administration to involve itself in this process mainly come from the Egyptian side. Ethiopia didn't ask for negotiation that can replace the earlier process. US Secretary Mnuchin prepared a draft paper about the filling and operation of the dam. However, the level of US intervention was high and the Trump Administration and the World Bank shifted their role from facilitator to one of the arbiters in the dispute. Thus, the meeting broke down in February 2020 after the US move its role as making the final agreement. The statement made by Secretary Mnuchin said that "final testing and filling should not take place without an agreement." Though the US didn't get full recognition as a negotiator from all the three states, the US government mainly the Treasury Office and the World Bank presented an agreement about the filling of the GERD and about the overall operation of the dam (Krampe et al., 2020). This issue clearly indicates that the US involvement in the process shows biasness to Ethiopia, a close ally in Middle Eastern politics. After this statement, the Ethiopian government rejects the US role in the negotiation and stressed its position to continue the agreement through the African-led mechanisms (Public Service Commission, 2020).

Ethiopia firmly stated that the filling of the dam will continue without getting any approval from anybody (Mehari, 2020). This is in accordance with the principle of the reasonable and equitable share of the water resource without causing significant harm to the riparian states. Egypt and Sudan call for the involvement of the U.N Security Council to stop Ethiopia from filling the dam before negotiation. The two countries separately appeal to the UN Security Council that without reaching a binding agreement the filling of the dam and its overall operation couldn't be resumed and it will cause security tensions in the region. However, Ethiopia demands the endorsement of the larger agreement of the Nile River basin and the process should include all the NBI states, though Egypt and Sudan didn't accept these demands (Krampe et al., 2020).

The Trump administration decided to suspend $\$ 100$ million in aid to Ethiopia as a result of the US biased statement about the negotiation process. However, the Biden Administration revoked this decision and changed the suspicion to other agendas (European Union, 2021).

Besides the US, other actors have also expressed their concerns in the GERD 
negotiation process. The European Union involved itself in the GERD negotiations as an observer and supported the AU-led process. The EU didn't put pressure through freezing funding like the US during the Trump Administration. For the EU, both Ethiopia and Egypt are their strategic partners in Northeastern Africa and the Horn of Africa. Therefore, the EU supported the AU efforts to mediate the GERD issue and reach into solution among the riparian states (European Union, 2021).

The other major concerned actor in the GERD negotiation is the Arab League (Egypt Today, 2021). The League consists of 22 member states which established in 1945 and headquartered in Cairo, Egypt. In its incessant meetings, the League offered its support for Egypt and Sudan in the GERD dispute and considered the water security of Egypt and Sudan as part of the Arab security. However, three member countries (Djibouti, Somalia and Qatar) have rejected the Arab League's resolution on the GERD dispute which is mainly dictated by Egypt. Thus, some writers stated that Egypt as a host of the Arab League used it as an instrument of manipulating its interest within the Arab region (Daily News Egypt, 2020). Thus, the intervention of the extra-regional actors within the GERD negotiation process has its own negative impact.

Generally, the inter-linkage of earlier contested negotiations on the utilization of the river, the nationalistic interest among the member states in the basin and the influence of the external actors complicated the process of establishing cooperation among the Nile Basin countries. Moreover, these three factors cumulatively came from both internal and external actors created a sense of mistrust and rivalry among the states in the basin.

\section{How the African Solutions to African Problems Can be Applied through the AU Led Mechanisms?}

\subsection{The AU Led GERD Negotiations}

After the failure of negotiations in the US, the three countries continued their discussions led by the AU. On July 21, 2020, the leaders of the three countries, Egypt, Sudan and Ethiopia agreed to continue the negotiations through the AU mechanisms. They are member of the AU and the organization has a better understanding and proximity to this agenda. The AU officials take the responsibility and the UN Security Council welcomed the facilitating role of the AU in the GERD negotiation process. Also, some of the officials expressed this approach as "window of hopes" (Public Service Commission, 2020).

The first meeting was chaired by the South African President Cyril Ramaphosa, first proposed by Ethiopian PM Abiy Ahmed, in his official visit to the Republic of South Africa asked the President to mediate the negotiations following the principle of solving African problems by African led mechanisms. At the time the South African President was the Chairperson of the AU. He initiated to play the facilitating role in the dispute and he discussed with the Heads of States of the three counties in the dispute (Ethiopia, Egypt and Sudan) and decided to 
intervene as negotiator in the process (Mehari, 2020).

The initial mediation process was conducted through virtual summit of the Bureau of Assembly of the AU (US Congress, 2020). After establishing the AU's role in the negotiations and appointed observers (4 in numbers) to observe the process. On June 26, 2020 and 2-13 July 2020, the AU led the first and second round meetings with the three riparian countries over the issue of GERD. After the completion of the meeting on June 27, 2020, the AU Chairperson, President Ramahposa and the AUC chairperson Mousa Faki Mohhamet states that "90\% of the issues of the negotiations between the three countries have been already resolved." In this meeting, five important decisions were made: 1) The three countries (Ethiopia, Egypt and Sudan) should refrain from making any statements or taking any actions that may jeopardize or complicate the AU-led process aimed at finding an acceptable solution on all outstanding matters; 2) It decided to "augment the Tripartite Committee dealing with the GERD issues consisting of Egypt, Ethiopia and Sudan with the participation of observers namely South Africa in its capacity as Chairperson of the AU, the Members of the Bureau of $\mathrm{AU}$, experts from the [AU] Commission"; 3) "The augmented Committee [is to] present its report to the Chairperson of the AU... within a week" from June 27 2020 (hence before July 5 2020); 4) The Bureau decided to reconvene the AU-led meeting within two weeks from June 272020 (i.e., before July 5 2020) and "consider a report on the outcome of the negotiations of the outstanding issues concerning the GERD matter"; 5) And finally, the Bureau requested the UN Security Council (UNSC) "to take note of the fact that the AU is seized of this matter" (Public Service Commission, 2020).

Following the end of the term, Ramaphosa handover his Chairmanship to the President of the Democratic Republic of Congo, Felix Tshisekedi. Therefore, in April 6, 2021, the three countries went to the Capital Kinshasa and continued their negotiations (European Union, 2021). Though the process is in its infant stage, it couldn't bring tangible results. The major disagreement points are about the filling process, the annual filling schedule and the issues of settlements on the future disputes. Egypt and Sudan asked for the involvement of other extra-regional actors mainly the US, UN and EU and the continental actors mainly the $\mathrm{AU}$ in the mediation process. This quadrilateral approach is first proposed by Sudan and endorsed by Egypt. Sudan's PM Abdullah Hamdok sent letter to the above-mentioned entities for the formation of the quartet mechanisms to lead the negotiation of the GERD. The letter was written on March 13/2021 following the agreement between the Egyptian President Abdulfettah El Sisi to invite the quadripartite actors in this process. In the quartet committee, the $\mathrm{AU}$ shall proceed to coordinate the negotiation process and other extra-regional actors involve in the process to support the negotiation. Moreover, the two countries came to a common position for the GERD negotiation to extent of safeguarding their interests through all means including military action. However, Ethiopia insists the AU-led mechanism in the GERD negotiation and other par- 
ties should not be part of the process (Egypt Today, 2021; European Union, 2021).

Considering the AU-led negotiations, the technical and legal issues mainly about the longer-term operation of the dam, dispute resolution mechanisms, future projects in the Nile River, and related issues have already been raised in the agreement. The major concern of Egypt and Sudan is getting guarantees about the outflow of the water keeping their historical average discharge. This includes getting compensation if the flow caused further damage for the upstream countries. Based on this concern, Egypt and Sudan want a binding agreement before the completion of the dam (Egypt Today, 2021).

On the other hand, Ethiopia argues that the requests of upstream countries mainly Egypt and Sudan are about the natural flow of the Blue Nile and this is completely untenable (European Union, 2021). Moreover, Ethiopia argues that it has a right to utilize its natural resources for future developments and the GERD is part of it. The major argument from the Ethiopian side is continuing the resolution mechanism based on the Declaration of Principles (DOP) which was signed between Ethiopia, Egypt and Sudan in March 2015 (Public Service Commission, 2020). Based on the DOP, "the three states will settle their conflicts emerging from the interpretation or implementation of this accord by consensus through consultations and negotiations". In the DOP major issues are reasonable and equitable use of the water resources and not to cause significant harm in the Nile Basin. This includes sharing important information about any projects in the river basin. Based on the DOP, it is stated that "the three states will settle their conflicts emerging from the interpretation or implementation of this accord by consensus through consultations and negotiations". Though the three countries signed the DOP, they can reach an agreement on the implementation of the principles. Ethiopia continuously urges the upstream countries to reach an agreement based on the DOP and having a treaty that enables for the equitable and fair share of the Nile Water as a viable option to avoid any future tensions among the Nile Basin countries (Misha, 2019).

In the process of the negotiation, the internal security concerns in Ethiopia, Sudan's transitional process, the border tensions between Ethiopia and Sudan further escalated the issue of negotiations on the GERD issue. Egypt and Sudan's officials expressed unilateral statements about the dam and even go to joint military exercise (European Union, 2021).

\subsection{The Implications of AU Led Negotiations}

Since the involvement of AU-led process in the GERD negotiations, there are few tangible results. Primarily, this is an important step to solve long-established river dispute. The three states agreed to resume the negotiations and understand the importance of establishing the African-led process. Also, this tradition will help to decrease tensions between the states. The AU became the center for GERD negotiations and was responsible for facilitating the process within the 
framework of continental mechanisms. The continental efforts encourage solving the transboundary resources disputes in Africa and can be taken as the best tradition of resolving the issues. If the GERD negotiation is successfully resolved through the AU-led mechanism, it can be a lesson for the other disputing agendas mainly in the transboundary resources management issues. The AU engagement in the GERD negotiation further supported to de-escalation of tensions among the three riparian countries. The technical and legal issues including the resolution mechanisms, filling and operation of the dam, future projects of the Nile River and the nature of the agreement to be signed. In order to prevent future disputes in the Nile Basin, the AU-led process is expected to bring an agreement that can avert the potential future tensions to use the water in an equitable way (US Congress, 2020; European Union, 2021).

Despite the ongoing efforts, the African-led process has a limitation of the legal framework on the use of water resources in the continent. Also, the major challenge of the AU-led negotiation is the lack of institutional and legal capacity that can mediate the transboundary resource management disputes. Also, agreements should be inclusive and should include all the riparian states. So far, the GERD dispute mainly concerned the three contending countries (Ethiopia, Egypt and Sudan), however, the issue of using Nile for development purposes concerns all the downstream and upstream countries. In order to continue the already established agreements and future disputes, the AU should have guidelines for mediation process. Besides, the legal frameworks, the AU has lacks the institutional capacity to mediate the water disputes. Moreover, there is a lack of sufficient experience in handling water resource management issues and resolving river disputes in the continent. For example, the African Union (AU) or the previous Organization of the African Unity (OAU) has no track record of solving the water disputes such as the largely disputed issues of the Nile River. Since the water disputes have the potential of creating regional as well as continental security, the African self-reliant conflict management and mediation capacity should be supported by strong institutional capacity. As it is observed in the GERD negotiation, the AU deployed ad hoc teams and there is also a lack of expertise in all fields related to solving the transboundary resource management issues in Africa (European Union, 2021; Public Service Commission, 2020). Therefore, in order to establish viable continental approaches, these existing challenges should be resolved.

Besides, Ethiopia has plans to launch more hydroelectric projects in the Nile River. Uganda has also planned to build hydroelectric dams in Lake Kyoga and Albert (Anwar, 2017). Therefore, this shows that there are increasing demands for the use of Nile River for future development plans. The rapid population growth, the low level of electric coverage, the development of industrialization and related factors contributed to the use of Nile Water to alleviate these challenges. Therefore, the AU needs an inclusive basin agreement that can prevent the future use of the Nile River. Also, enhancing inclusive transboundary resource 
management mechanisms and basin-wide frameworks are very decisive to foster stability in the future.

\subsection{Sustainable Solutions: Enhancing Sub-Regional Mechanisms}

Besides, the AU-led mechanism; there are sub-regional arrangements in resolving the Transboundary resource disputes in the Nile River Basin. The first option is enhancing the Nile Basin Initiative (NBI) and the second one is establishing the Nile Basin Framework. Among all the initiatives, to alleviate the Nile River dispute, the best framework is through the NBI. This framework can help the countries to have the best principles and rights for the transboundary resources management through the Nile River (Abadir, 2011).

The first attempts to establish cooperation among the Nile Basin was started during the Egyptian occupation in 1882 (Any Freitas, 2013). At the time the intention was to build various dams in the Nile River and signed various agreements about the utilization of the river (Dahilon, 2003). This colonial time idea mainly mentioned the following provisions; no project is can be conducted which affects the flow of the Nile river, can't reduce the flow of the river or lower its level. In the Nile River dispute, one of the major challenges is the interest of pursuing the British ideas on the side of the Egyptian government. Prior to the establishment of NBI, Egypt and Sudan recommend the establishment of the Nile Basin Commission in 1978. However, due to the upstream states, the initiative couldn't represent the interest of all the concerned states in the Nile river basin. Mainly the 1959 agreement created suspicion and a sense of mistrust among the member states in the basin (Dereje, 2010).

In 1999, member states in the basin established the Nile Basin Initiative (NBI) which aimed to facilitate equitable and sustainable development and management of shared water resources in the Nile basin (Dahilon, 2003). The major objective of NBI is the achievement of sustainable socio-economic development through the equitable utilization of the Nile Basin water resources. The organization is aimed to manage relations among states in the Nile River (Yaekob, 2011). The river covers 6,700 kilometers and eleven countries became part of the NBI. The Nile Basin Initiative (NBI) consists of ten member states Burundi, the Democratic Republic of Congo, Egypt, Eritrea, Ethiopia, Kenya, Rwanda, Sudan, Tanzania and Uganda. The Upstream and downstream have different and unequal shares of the Nile River. At the first time, the NBI was launched in Uganda, Entebbe after series of discussions from 1993-2002. This initiative is considered an important step in the Nile river basin since it incorporated all the Nile Basin countries. The NBI is responsible for facilitating cooperation among the states in the Nile River and up to now laid foundations for establishing treaties and served as a platform for bringing states together to settle their disputes (Anwar, 2017).

The major factors for the establishment of institutional-based cooperation in the Nile river basin are due to the population growth and the need to establish 
irrigation-based agriculture, both the downstream and upstream countries understood the need for establishing comprehensive arrangements about the use of this transboundary resource, the external actors' influence mainly from the international donors in the region seek the establishment of institutionalized cooperation among the Nile river basin. During the formation of the NBA, member states emphasized the need for a win-win approach rather than a win-lose approach in the basin. However, the NBI couldn't bring meaningful results due to various reasons. The major causes are the lack of member states' commitment to accept cooperative agreements. Though most of the countries in the region are members of the NBI, member states engaged in unilateral ways and conduct projects based on their national interests (Krampe et al., 2020).

Under the platform of the NBI, the Nile Basin Cooperative Framework is signed in May 2010 mainly reinforced by the upstream countries. This framework claims the rights of using the Nile River and further states that legal tools should be applied to use the river for the mutual benefit of all the riparian countries in the basin. Moreover, the signatories used this framework mainly to challenge the Egyptian hegemonic actions in the Nile River. Thus Egypt and Sudan didn't sign in this framework and its legal viability is in question (Abadir, 2011).

The CFA aimed to replace the old versions of Nile Basin agreements and established newly designed frameworks to use the river with a mutually beneficial way. The idea of establishing this framework came after a long period of discussions and treaties between the NBI member states. The CFA not only established a framework based on the principles of international law but also introduced the concept of equitable use of the water with fair mechanisms and gives emphasis to the importance of multilateral basin-based institutional arrangements (Dereje, 2010).

Among the eleven NBI member states, six of them (Burundi, Ethiopia, Uganda, Rwanda, Kenya and Tanzania) have signed the CFA. The Democratic Republic of Congo and South Sudan have the interest to sign but have not signed yet. Egypt refrained from signing the CFA and in 2010 proposed major areas of amendments before signing the agreements. These requests include the approval of all the projects in the basin, getting a guarantee of 55.5 billion cubic meters annual flow of water and thirdly and the water security on the current uses of the Nile Basin. The Egyptian objections mainly focused on maintaining the veto power on the issue of the river basin and getting an unfair allocation of the shared resources. Thus, the demands can be taken as the extension of the colonial area agreements and hampered the process of African-led resolution mechanisms. The basic themes of the CFA signify the principles of water security and the equitable and reasonable use of the Nile River. Based on the CFA, the use of Nile Water is mainly related to alleviating poverty and using the water resource for economic development activities such as agriculture, livelihood production and environmental protection. Therefore, the CFA through NBI can be taken as the best model for the biding framework in the basin (Dereje, 2010; Krampe et al., 2020). 


\section{Conclusion}

The issue of preventing future tensions among the Nile Basin countries is an important political, economic as well as security agenda in Africa. Mainly, it is a source of contention among the riparian countries (Ethiopia, Egypt and Sudan). The major hindrances of cooperation in the Nile River Basin are relying on national interest and member states' unilateral actions as well as mistrust and rivalry among the states. The major contradiction of the Nile Dispute can be explained that the downstream countries Egypt and Sudan demands the preservation of historical usage of the river which offers them the exclusive usage of the river, whereas the upstream countries mainly Ethiopia, strictly demand an increasing share and utilization of the river.

Therefore, establishing conflict resolution mechanisms through the African-led process would give a better chance to foster peace and stability in the Northeastern African region and in the continent. In order to prevent the possibility of conflicts over the issue of transboundary water resources, the AU needs to establish a continental-wide mechanism for resolving the disputes and mediating all the riparian countries on the river. The best way to solve the long-established dispute is through maintaining cooperation in the African-led initiatives. The eleven riparian countries in the Nile River should establish their relations based on the mutually beneficial way. The Nile River is a shared resource and should be managed in a shared principle and must be approached in the legally binding cooperation to alleviate poverty in the basin.

Moreover, colonial time negotiations should represent the current reality and monopoly of the natural resources couldn't be practical. The states in the Nile Basin need a shared platform that can provide a collaborative framework based on international law. The relations between NBI should be based on multilateral mechanisms and all the riparian states should establish rule-based and mutually beneficial diplomatic relations. The agreements among the riparian states should be through African-led mechanisms to strengthen the concept of solving African problems by African mechanisms. This approach allows adopting win-winning situation by avoiding gaining relative gains and the long-lasting culture of zero-sum approaches. The African regional institutions including the $\mathrm{AU}$ and other sub-regional organizations also can be served as instruments of cooperation among the riparian states in the Nile River. Therefore, the enduring tensions and rivalries could be mitigated through cooperation and the people in the Nile River Basin can be beneficial from the natural resources and alleviate poverty.

\section{Conflicts of Interest}

The author declares no conflicts of interest regarding the publication of this paper.

\section{References}

Abadir, M. I. (2011). The Nile Basin Cooperative Framework Agreement: The Beginning 
of the End of Egyptian Hydro-Political Hegemony. Journal of Environmental and Sustainability Law, 18, Article No. 4.

Anwar, H. T. (2017). The Geopolitics of Water Negotiations Succeeding the GERD Project in the Nile River Basin: The Case of Ethiopia, Egypt, and Sudan (p. 34). Insamer Research Center.

Any Freitas (2013). Water Politics in the Nile Basin (pp. 1-2). European Union Institute for Security Studies.

Bearak, M., \& Raghavan, S. (2020, November 14). Africa's Largest Dam Powers Dreams of Prosperity in Ethiopia-And Fears of Hunger in Egypt. Washington Post. https://www.washingtonpost.com/

Claudious Chikozho, C. (2012). Towards Best-Practice in Transboundary Water Governance in Africa: Exploring the Policy and Institutional Dimensions of Conflict and Cooperation over Water. In K. T. Hanson, G. Kararach, \& T. M. Shaw (Eds.), Rethinking Development Challenges for Public Policy (pp. 155-200). Palgrave, Macmillan. https://doi.org/10.1057/9780230393271_6

Dahilon, Y. M. (2003). Nile Basin Cooperation: A Review of the Literature (No. 26, pp. 1-41). Current African.

Daily News Egypt (2020, June 24). Arab League Adopts Resolution Supporting Egypt, Sudan in GERD Talks. Daily News Egypt.

https://dailynewsegypt.com/2020/06/24/arab-league-adopts-resolution-supporting-egy pt-sudan-in-gerd-talks/

Dereje, Z. M. (2010). The Nile Basin Cooperative Framework Agreement Negotiations and the Adoption of a 'Water Security' Paradigm: Flight into Obscurity or a Logical Cul-de-sac? European Journal of International Law, 21, 421-440. https://doi.org/10.1093/ejil/chq027

Egypt Today (2021, May 28). Egyptian, Sudanese 'Nile Guardians' Joint Military Exercise Kicks Off. Egypt Today.

https://www.egypttoday.com/Article/1/104396/Egyptian-Sudanese-'Nile-Guardians'-joi nt-military-exercise-kicks-off

El-Fadel, M., El-Sayegh, Y., El-Fadl K., \& Khorbotly, D. (2003). The Nile River Basin: A Case Study in Surface Water Conflict Resolution. Journal of Natural Resources and Life Sciences Education, 32, 107-117. https://doi.org/10.2134/jnrlse.2003.0107

European Union (2021). New Ethiopian Dam Sparks Controversy among Nile States. European Parliamentary Research Service.

Faibt, R. (2019). How Mediation Based on African Approaches to Conflict Resolution Can Transform the Conflict over the Nile. Conflict Trends, 2019, 29-37.

John, M. M. (2020). The Controversy over the Grand Ethiopian Renaissance Dam. Africa in Focus, 5, 1-6.

Krampe, F., van de Goor, L., Barnhoorn, A., Smith, E., \& Smith, D. (2020, March). Water Security and Governance in the Horn of Africa. SIPRI Policy Paper No. 54, Stockholm International Peace Research Institute.

Laurie, N. (2013). African Solutions to African Problems: South Africa's Foreign Policy. Zeitschrift für Internationale Politik, 1, 48-55.

Lidet, T. S. (2019). Peace and Security in Africa: Drivers and Implications of North Africa's Southern Gaze. Discussion Paper, European Centre for Development Policy Management.

Mays, T. M. (2003). African Solutions for African Problems: The Changing Face of African-Mandated Peace Operations. Journal of Conflict Studies, 23, 106-125. 
Mehari, T. M. (2020, June). The Nile Rivalry and Its Peace and Security Implications: What Can the African Union Do? Policy Brief, 1, 1-13.

Misha, K. (2019, February 25). The Grand Ethiopian Renaissance Dam Is the New Reality. Why a Deal Must Be Done. The Conversation Africa.

Mulat, A., \& Moges, S. (2014). Assessment of the Impact of the Grand Ethiopian Renaissance Dam on the Performance of the High Aswan Dam. Journal of Water Resource and Protection, 6, 583-559. https://doi.org/10.4236/jwarp.2014.66057

Public Service Commission (2020). The AU's Role beyond the GERD Negotiations. International Security Studies.

Rawia, T. (2018). Conflict and Cooperation in the Eastern Nile: The Role of Business (pp. 34-45). African Peacebuilding Network No. 26, Social Science Research Council.

Remofiloe, L. (2017). African Solutions to African Problems: A Viable Solution towards a United, Prosperous and Peaceful Africa (PP. 1-13)? Institute for Global Dialogue, Universitas Islam Negeri Sunan Ampel.

Tesfa, B. (2013). Benefit of Grand Ethiopian Renaissance Dam Project (GERDP) for Sudan and Egypt. EIPSA Communicating Article: Energy, Water, Environment \& Economic.

Treszkai, Á. (2018). General Overview of the Consequences of African Water Conflicts. UKH Journal of Social Sciences, 2, 11-18. https://doi.org/10.25079/ukhjss.v2n2y2018.pp11-18

US Congress (2020). The Nile Dam Dispute: Issues for Congress. US Congress Service.

Yaekob, M. A. (2011, December). Conflict and Cooperation among the Nile Basin Countries with Special Emphasis on the Nile Basin Initiative (NBI). Graduate School of Development Studies.

Yihdego, Z., Rieu-Clarke, A., \& Cascão, A. E. (2016). How Has the Grand Ethiopian Renaissance Dam Changed the Legal, Political, Economic and Scientific Dynamics in the Nile Basin? Water International, 41, 503-511. https://doi.org/10.1080/02508060.2016.1209008

Yohannes, Y., Alamgir, K., \& Sale, H. S. (2017). Nile River's Basin Dispute: Perspectives of the Grand Ethiopian Renaissance Dam (GERD). Global Journal of Human-Social Science, 17, 45-56. 